\title{
Assessing recent environmental sustainability in the Spanish network of National Parks and their statutory peripheral areas
}

\author{
David Rodríguez-Rodríguez ${ }^{1,2} \&$ Javier Martínez-Vega ${ }^{1}$ \\ ${ }^{1}$ Institute of Economy, Geography and Demography, Spanish National Research Council (IEGD-CSIC) \\ Associated Unit GEOLAB. C/Albasanz, 26-28; 28037, Madrid, Spain. \\ ${ }^{2}$ University of Malaga, Andalucía Tech, European Topic Centre-Universidad of Malaga. Campus de Teatinos s/n, 29010 Málaga, \\ Spain
}

Abstract Land use-land cover (LULC) changes and wildfires in the Spanish Network of terrestrial National Parks (NPs) and their legally designated peripheral areas, including Peripheral Protection Zones (PPZs) and Socioeconomic Influence Zones (SIZs), were assessed as indicators of recent territorial environmental sustainability trends. Level three, Corine Land Cover (CLC) data between 2005 and 2011 were compared. Official wildfire digital data were obtained from the European Commission for the 2005-2011 period. Results show increasing numbers of LULC changes along the protection gradient: NPs < PPZs < SIZs. NPs were, in general, highly stable regarding LULC changes and less affected by wildfires, which suggests high environmental effectiveness of legal and managerial protection afforded to the Spanish NP Network. Three study areas (SAs) were very stable in the analysed period in all their zones: Aigüestortes, Ordesa y Monte Perdido and Caldera de Taburiente. In turn, Teide and Doñana were the SAs where LULC changes were more abundant. Unsustainable LULC changes concentrate in NPs' peripheral areas, chiefly in their SIZs, with wildfires being the most widespread pressure in the analysed period. Teide's SA outstands due to its environmentally unsustainable recent LULC changes, with urbanisation and wildfires affecting natural and semi-natural areas. Sustainable territorial planning and management practices should prioritise this SA.

Keywords: Reserve; zoning; land use-land cover transition; forest fire; Spain

\section{Introduction}

Global biodiversity is going through an unprecedented decline due to human activities (Butchart et al., 2010). To revert such decline, almost all countries and territories have designated protected areas (PAs) to conserve important genes, species and ecosystems in the long term under dozens of legal designation categories (Dudley, 2008). As such, PAs can be considered the paradigm of environmental sustainability (Rodríguez-Rodríguez \& Martínez-Vega, 2013). The environmental sustainability of peripheral areas of PAs is also an important concern as external pressures resulting from activities developed in surrounding areas are likely to have an impact on protected biodiversity and reduce PA conservation effectiveness (Mcdonald et al., 2009; Radeloff et al., 2010; Gimmi et al., 2011; Xun et al., 2014). As a result, surrounding areas subject to progressively more lenient regulations from PA boundaries aimed at making biodiversity conservation and local socioeconomic development compatible have been proposed (Sabatini et al., 2007; Geneletti
\& van Duren, 2008; Ahmad et al., 2012) and implemented, rendering some positive environmental and socioeconomic outcomes (Allendorf \& Gurung, 2016). That protectiondevelopment gradient is precisely the philosophy behind some worldwide networks of PAs and sustainable areas such as Biosphere Reserves (UNESCO, 2016).

Spain is a biodiversity-rich country of approximately 500,000 km2 in south-western Europe (Medail \& Quezel, 1999; Prieto, 2014). It is located in the Mediterranean global biodiversity hotspot (Myers et al., 2000) and spans across four biogeographic regions: Alpine, Atlantic, Mediterranean and Macaronesian (EEA, 2015; Spanish Government, 2016a). Spain is also a highly decentralised country, with most environmental policies transferred to the 17 autonomous regions and the 2 autonomous cities in the country. In the case of NPs, the Spanish Government is competent for the designation of new NPs, for making and passing basic legislation on NPs that includes common designation and planning objectives (Spanish Government, 2014) and for producing the 
Director Plan of the NP Network which establishes common management criteria for the network (Spanish Government, 2016b).

'National Park' is defined by the Spanish law on NPs as: 'little transformed natural areas of high ecological and cultural value that, because of their landscape beauty, ecosystem representativity, and/or floral, faunal or geological singularity, have ecological, aesthetic, cultural, educational or scientific values whose conservation is of general interest to the State' (Spanish Government, 2014). The main objective of the Spanish Network of NPs is to preserve the integrity of their natural assets and landscapes and, secondarily, to cater for social enjoyment, environmental outreach, scientific research and sustainable development of local populations (Spanish Government, 2014). As such, the Spanish definition of NP aligns closely with the definition of IUCN's PA Management Category II that primarily aims to 'protect natural biodiversity along with its underlying ecological structure and support environmental processes, and to promote education and recreation' (Dudley, 2008).

LULC changes largely result from the development model of societies and have great implications for biodiversity and ecosystem service provision (EEA, 2006; Jiménez, 2012). Sustainability objectives of PAs often collide with unsustainable sectoral policies, such as transport, housing or agricultural policies that insufficiently consider environmental assets through sound territorial planning and result in unsustainable LULC changes (EEA, 2006; Prieto, 2014). Thus, LULC change has been proposed and often used as an essential indicator of environmental sustainability of ecological units (Newbold et al., 2016), territories (EEA, 2006; Jiménez, 2012), PAs (Gaston et al., 2008; Terra et al., 2014; Martínez-Fernández et al., 2015) and their surrounding areas (Radeloff et al., 2010; Martinuzzi et al., 2015). Actually, differences in biodiversity status between protected and unprotected sites are chiefly related to differences in LULCs (Gray et al., 2016). Massive unsustainable LULC changes occurred across Spain in the 1990-2000 decade and, predominantly, between 2000 and the burst of the housing bubble in 2008, which resulted from enormous investment in real estate through critically exposed credits (Jiménez, 2010; Alfonso et al., 2016). Those LULC changes threatened the natural values for which NPs and other PAs were designated, especially around densely populated areas like Barcelona (Mallarach, 2008), Madrid (RodríguezRodríguez, 2008; Rodríguez-Rodríguez \& Martínez-Vega, 2013; Gallardo and Martínez-
Vega, 2016) and along the coast (Prieto, 2014; Alfonso et al., 2016).

Forest fires form part of the ecological dynamics in Mediterranean ecosystems (Moreno, 1989; Pausas \& Vallejo, 1999). However, human activities often modify natural fire regimes resulting in shifting fire frequency, intensity and seasonality. This may overcome ecosystems' resilience and permanently turn them to different stages of their succession processes, with serious consequences for biodiversity (Pausas, 1999; Pérez-Cabello \& De la Riva, 2001). In Spain, both the number of wildfires and their extent notably decreased between 1991-2000 and 2001-2010 as a result of increased and more effective prevention and extinction means (Enríquez \& del Moral, 2012). However, wildfires are still the main factor reducing forest cover, maturity and quality in Spain (Pérez-Cabello \& De la Riva, 2001; Prieto, 2014). They cause biomass loss, forest rejuvenation, reduced ecological and productive value and increased soil erosion (Prieto, 2014). Thus, it is advisable to analyse the environmental sustainability of recent LULC changes and wildfire extent in the Spanish Network of National Parks and in their peripheral areas in order to detect positive trends towards 'naturalness' or, inversely, negative trends towards 'anthropisation' of those natural assets of the utmost importance.

\section{Methods}

\subsection{Study scope}

The Spanish law on NPs (Spanish Government, 2014) defines three general statutory zones that can be applied to NPs: 1) Socioeconomic Influence Zones (SIZs); 2) Peripheral Protection Zones (PPZs); and 3) NPs. We will refer to the three statutory zones of each site as 'study area' (SA). SIZs are made of the entire territory of the municipalities whose areas are totally or partially included in the NP. These municipalities are entitled to state subsidies to offset land management limitations as a result of NP's regulations. PPZs are terrestrial or marine areas external and contiguous to NPs that are subject to some regulations aimed at buffering the external impacts on NPs. NPs include the perimeters of the actual PAs which must be (and are normally) also zoned according to planning and managerial needs (Spanish Government, 2012a). By September of 2017, all the fifteen NPs of the Spanish NP Network had SIZs and ten of them had PPZs.

Twelve of the 15 NPs that made the Spanish NP Network were selected for this study on the 
grounds of designation dates and main realm of protected ecosystems. They represent $85 \%$ of the whole NP network area, $83 \%$ of the PPZ area in the network, and $87 \%$ of the SIZ of the network by September of 2017. These 12 NPs are scattered across the four biogeographical regions in the Spanish terrestrial territory (EEA, 2015; Fig. 1). Appendix 1 summarises the main characteristics of the selected NPs.

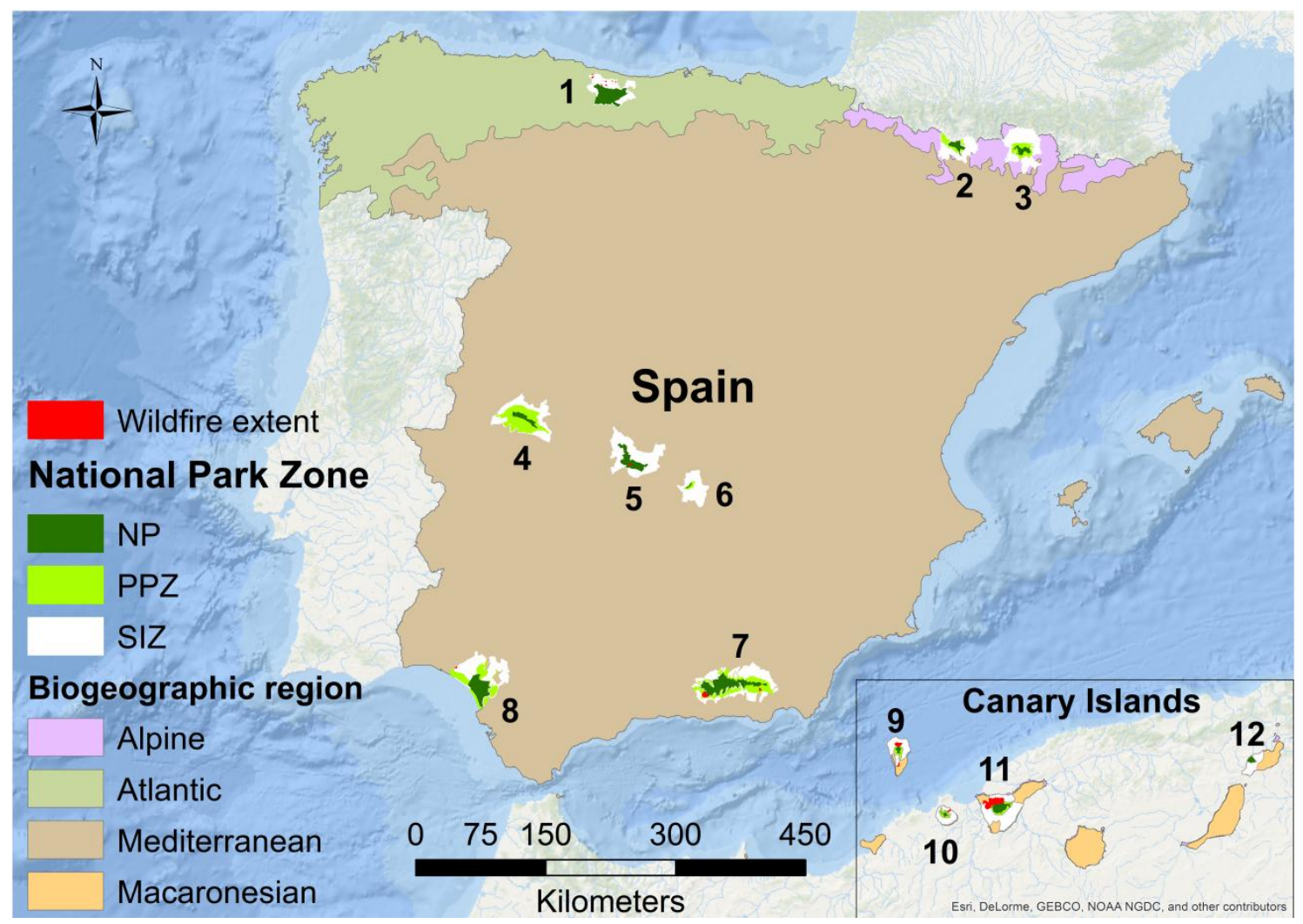

Fig.1. Wildfire extent in each assessed national park network zone across the Spanish biogeographic regions for the 2005-2011 period

Numbers represent study areas: 1) Picos de Europa; 2) Ordesa y Monte Perdido; 3) Aigüestortes i estani de Sant Maurici; 4) Monfragüe; 5) Cabañeros; 6) Tablas de Daimiel; 7) Sierra Nevada; 8) Doñana; 9) Caldera de Taburiente; 10) Garajonay; 11) Teide; 12) Timanfaya. NP: National Park; PPZ: Peripheral Protection Zone; SIZ: Socioeconomic Influence Zone

\subsection{Spatial-statistical analysis.}

The official digital layers of the different statutory zones of the terrestrial NPs (Spanish Government, 2016c) were intersected with Corine Land Cover (CLC)-2006 and CLC-2012 level-3 data. Versions 18.5 of CLC 2006 and 2012 (Copernicus, 2016 $\mathrm{a}, \mathrm{b}$ ) were used for being the most updated consistent and comparable repository of LULC data at European scale (Maucha \& Buttner, 2005; Hewitt et al., 2016). From the current 15 Spanish NPs by September of 2017, only those terrestrial NPs designated until the median CLC-2006 scene dates (July 2005) were selected to be sure that they had been NPs for the whole analysed period $(n=11)$. Monfraguie NP, designated in March of 2007, was also included in the set of analysed NPs, as it had been previously designated as Nature Park (so no major LULC changes were expected between July 2005 and March 2007) and was designated as NP for the most part of the analysed period (July 2005 till June 2011 on average).

LULC change (C) was calculated subtracting the percentage of each CLC level 3 LULC in 2005 from that percentage in 2011 by each SA and statutory zone of the whole network of sites:

$$
C=L U x, i(2011)-L U x, i(2005)
$$

where LU is the percentage of coverage of LULC $x$ in SA or zone $i$. The LULC change thresholds we used are quite modest: we considered 'noticeable' change those LULC changes that affected $\geq \pm 0.1 \%$ of the area of the analysed SA or zone, and 'relevant' change, all LULC changes affecting $\geq \pm 1 \%$ of that area in the considered period. Pearson correlation analysis between the number of noticeable LULC changes and each SA's area and NP's age was performed to assess whether LULC changes might be driven by the amount of area assessed or by social recognition of the site, 
respectively, after checking the normality of variables. As official SIZs included the whole area covered by NPs and PPZs (when these exist), the area of both zones was subtracted from SIZ area values for each site, so the three zones were spatially mutually exclusive and legally ranked in decreasing degree of protection (Spanish Government, 2014).

The aim of any PA should be to conserve biodiversity and associated ecosystem services and cultural values in the long term while maintaining or increasing the naturalness of the ecosystems being protected (Dudley, 2008). Therefore, LULC changes or processes towards more natural, less intensive ecosystems (e.g. natural succession; ecological restoration; agricultural extensification) were considered as environmentally sustainable whereas changes that reduce naturalness or increase LULC intensity (e.g. artificialisation; degradation of vegetation; agricultural intensification) were considered as environmentally unsustainable (Kuemmerle et al., 2016). The sustainability of stable LULCs was not analysed. We however assessed initial LULCs around NPs (in their SIZs) by 2005 (Copernicus, 2016 a ) as a proxy of the degree of starting human pressure on them.

The analysed period is relatively short to clearly detect some natural LULC changes such as succession, with the exception of sudden, landscape-impacting events such as landslides or naturally-caused forest fires (Nieto et al., 2012). It is however long enough to detect rapid human-made changes, such as urbanization, human-induced wildfires or conversion to agricultural land (EEA, 2006). Thus, our shortterm analysis of environmental sustainability is likely biased towards negative LULC changes, which tend to occur and be registered faster than changes towards 'naturalness'. 'Relevant' LULC transitions were assessed from a qualitative environmental sustainability viewpoint accounting for factors such as foreseen variation in water consumption, soil erosion, soil sealing, carbon sequestration, probability of wildfires, or proximity to climax (EEA, 2006). For this, we unioned $t_{1}$ (2005) and $t_{2}$ (2011) LULC layers to provide finer detail by
SA and zone for site managerial purposes. Only LULCs and LULC changes of at least tha were analysed, as smaller polygons were mostly digital layer alignment errors.

Finally, a forest fire GIS layer including all wildfires that were registered in Spain in the 2005-2011 period provided by the European Commission's Joint Research Centre (SanMiguel-Ayanz, 2012) was intersected with the $t_{1}$ LULC layer to ascertain the location, affected LULCs and extent of wildfires affecting the NP network for being a common pressure to Spanish ecosystems (Prieto, 2014) and PAs, including NPs (Spanish Government, 2012a; Hewitt et al., 2016). All calculations were made using Arc-GIS V.10.3 in the ETRS 1989 LAEA projection and Microsoft Excel.

\section{Results}

\subsection{Initial human pressure around national parks}

Ninety-two point three per cent of all area in SIZs of the Spanish NP Network was natural or seminatural by 2005 . The LULCs covering the greatest proportion of SIZs were 'coniferous forest' (12.47\%), 'sclerophyllous vegetation' $(12.34 \%)$ and 'non-irrigated arable land' (10.80\%). Only $7.7 \%$ of initial SIZ area included clearly environmentally unsustainable LULCs (i.e., permanently irrigated land, artificial areas or burnt areas). Table 1 shows the main initial LULCs and the proportion of unsustainable LULCs around each NP and PPZ by 2005 .

\subsection{LULC changes in the network}

Fifty-six per cent of all the network area (all SAs) where 'relevant' LULC changes occurred experienced negative LULC changes; $32 \%$ of that area experienced positive changes, and $12 \%$ of that area underwent changes that could be considered equivalent from an environmental sustainability perspective (Appendix 2). 
Table 1. Main land uses-land covers (LULCs) and proportion of environmentally unsustainable LULCs (permanently irrigated land, artificial areas or burnt areas) in socioeconomic influence zones of Spanish national parks by 2005

\begin{tabular}{|c|c|c|c|}
\hline National Park & Main LULC & $\begin{array}{l}\text { Proportion of main } \\
\text { LULC }(\%)\end{array}$ & $\begin{array}{l}\text { Proportion of unsustainable } \\
\text { LULCs }(\%)\end{array}$ \\
\hline Doñana & Rice fields & 21.02 & 33.04 \\
\hline Timanfaya & Bare rock & 37.04 & 12.90 \\
\hline Monfragüe & Agro-forestry areas & 43.68 & 9.62 \\
\hline Teide & Coniferous forest & 28.14 & 9.58 \\
\hline Sierra Nevada & $\begin{array}{l}\text { Sclerophyllous } \\
\text { vegetation }\end{array}$ & 24.8 & 7.83 \\
\hline Tablas de Daimiel & $\begin{array}{l}\text { Non-irrigated arable } \\
\text { land }\end{array}$ & 42.11 & 5.71 \\
\hline Garajonay & $\begin{array}{l}\text { Sclerophyllous } \\
\text { vegetation }\end{array}$ & 31.68 & 1.79 \\
\hline Caldera de Taburiente & Coniferous forest & 30.3 & 1.64 \\
\hline Cabañeros & $\begin{array}{l}\text { Non-irrigated arable } \\
\text { land }\end{array}$ & 24.89 & 1.20 \\
\hline Aiguestortes & Natural grassland & 28.14 & 0.78 \\
\hline Picos de Europa & Moors and heathland & 34.62 & 0.35 \\
\hline Ordesa y Monte Perdido & Coniferous forest & 38.15 & 0.10 \\
\hline
\end{tabular}

\subsection{LULC changes by study area}

Three SAs showed great stability of LULCs, with no 'noticeable' changes in the analysed period: Aigüestortes, SA, Caldera de Taburiente's SA and Ordesa y Monte Perdido's SA. On the contrary, Teide's SA and Doñana's
SA were the most dynamic SAs, experiencing the highest numbers of 'noticeable' LULC changes (Fig. 2). No statistically significant correlation was found between the number of 'noticeable' LULC changes and study areas' sizes or NPs' ages.

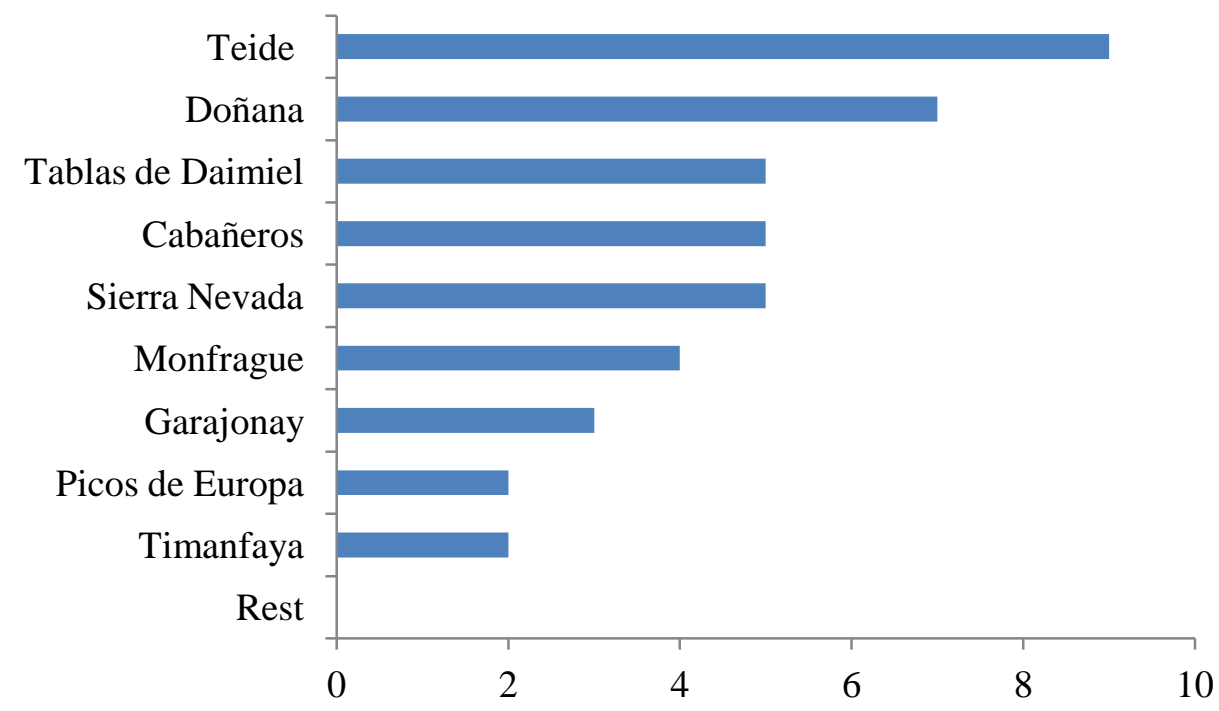

Fig. 2. Number of noticeable LULC changes by study area 
All the 'relevant' LULC changes of the network occurred in Teide's SA. The $15.40 \%$ absolute change of 'continuous urban fabric' in Teide' SA was the greatest LULC change of the entire network by far. It mostly occupied land previously covered by 'pastures' $(-6.59 \%$ of the whole LULCs in the SA), 'sparsely vegetated areas' $(-5.89 \%)$, 'fruit trees and berry plantations' (-1.65\%) and 'moors and heathland' (-1.17\%). Actually, 'pastures' and 'moors and heathland' disappeared as LULCs from the Teide's SA in 2012. Most SAs experienced overall negative environmental sustainability trends of LULC change in the considered period (Table 2). Appendix 2 summarises 'relevant' LULC transitions in the most dynamic SAs.

Table 2. Estimated environmental sustainability of 'relevant' land use-land cover changes in Spanish national parks by study area between 2005 and 2011

\begin{tabular}{lllll}
\hline Study area & \multicolumn{3}{l}{ Environmental sustainability } & \\
\cline { 2 - 5 } & $\begin{array}{l}\text { Positive } \\
\text { changes }(\%)\end{array}$ & $\begin{array}{l}\text { Equivalent } \\
\text { changes }(\%)\end{array}$ & $\begin{array}{l}\text { Negative } \\
\text { changes }(\%)\end{array}$ & Overall trend \\
\hline Cabañeros & 35.70 & 0.00 & 64.30 & Negative \\
Doñana & 47.60 & 2.60 & 49.80 & Negative \\
Garajonay & 0.00 & 0.00 & 100 & Negative \\
Monfragüe & 24.84 & 8.66 & 66.50 & Negative \\
Picos de Europa & 100 & 0.00 & 0.00 & Positive \\
Sierra Nevada & 18.55 & 0.00 & 81.45 & Negative \\
Tablas de Daimiel & 24.06 & 56.28 & 19.66 & Positive \\
Teide & 7.86 & 5.49 & 86.65 & Negative \\
Timanfaya & 64.77 & 29.55 & 5.68 & Positive \\
\hline
\end{tabular}

\subsection{LULC changes by statutory zone.}

Inside NPs, only three LULCs experienced 'noticeable' change between 2005 and 2011: 'transitional woodland shrub' $(+0.40 \%)$, 'coniferous forest' $(-0.36 \%)$ and 'broad-leaved forest' $(-0.10 \%)$. In PPZs, 'transitional woodland shrub' and 'inland marshes' increased (by $0.32 \%$ and $0.13 \%$, respectively), whereas 'coniferous forest' $(-0.18 \%)$, 'sclerophyllous vegetation' $(-0.15 \%)$ and 'pastures' $(-0.13 \%)$ decreased. In SIZs, two LULCs increased noticeably: 'continuous urban fabric' $(+2.14 \%)$ and 'transitional woodland shrub' $(+0.20 \%)$, and six LULCs decreased noticeably: 'pastures' $(-0.89 \%)$, 'sparsely vegetated areas' $(-0.82 \%)$, 'fruit trees and berry plantations' $(-0.20 \%)$, 'moors and heathland' $(-0.16 \%)$, 'broad-leaved forest' $(-0.13 \%)$ and 'mixed forest' $(-0.10 \%)$. Table 3 shows descriptive statistics on LULC change by zone.

Table 3. Summary statistics of the three statutory zones of the Spanish network of national parks NP: National Park; PPZ: Peripheral Protection Zone; SIZ: Socioeconomic Influence Zone

\begin{tabular}{|c|c|c|c|}
\hline & \multicolumn{3}{|c|}{ Statutory network zones } \\
\hline & NP & PPZ & SIZ \\
\hline Area (ha) & 326,546 & 311,618 & 921,143 \\
\hline $\begin{array}{l}\text { Number of noticeable LULC } \\
\text { changes }\end{array}$ & 3 & 5 & 8 \\
\hline Mean LULC change (\%) & 0.00 & 0.00 & 0.00 \\
\hline Median LULC change (\%) & 0.00 & 0.00 & 0.00 \\
\hline $\begin{array}{l}\text { Standard deviation of LULC } \\
\text { change }(\%)\end{array}$ & 0.10 & 0.07 & 0.39 \\
\hline $\begin{array}{l}\text { Absolute range of LULC } \\
\text { change }\end{array}$ & 0.76 & 0.49 & 3.03 \\
\hline
\end{tabular}




\subsection{Impact of wildfires by $S A$ and statutory zone}

Seven SAs (58\%) were affected by forest fires between 2005 and 2011. In them, six SIZs, four PPZs and five NPs were affected (Table 4). The proportion of each statutory zone affected by wildfires was between 3.6 times (Teide SA) and 96 times (Picos de Europa SA) smaller in NPs than in SIZs for those SAs in which wildfires affected both zones, except in Sierra Nevada SA, where the proportion of burnt NP was nearly 14 times greater than the proportion of burnt SIZ. The proportion of burnt NPs was also smaller in NPs than in PPZs in SAs where both zones were affected by wildfires. In two SAs, their SIZs were more affected by wildfires than their PPZs, whereas in two other SAs the opposite occurred.

Table 4. Percentage of statutory zone affected by wildfires by study area between 2005 and 2011

NP: National Park; PPZ: Peripheral Protection Zone;

\begin{tabular}{lll}
\multicolumn{2}{c}{ SIZ: Socioeconomic Influence Zone } \\
\hline Site & Zone & $\begin{array}{l}\text { Area } \\
\text { affected } \\
(\%)\end{array}$ \\
\hline Teide & SIZ & 11.56 \\
& PPZ & 15.75 \\
Caldera de Taburiente & NP & 3.22 \\
& SIZ & 5.08 \\
Sierra Nevada & PPZ & 5.06 \\
& NP & 0.27 \\
Garajonay & SIZ & 0.08 \\
& PPZ & 2.52 \\
Picos de Europa & NP & 1.10 \\
& SIZ & 1.27 \\
Cabañeros & PPZ & 1.25 \\
Doñana & SIZ & 0.96 \\
\hline
\end{tabular}

\subsection{Impact of wildfires by LULC}

'Sclerophyllous vegetation', 'broad-leaved forest', 'coniferous forest', 'land principally occupied by agriculture' and 'transitional woodland shrub' were the LULCs where most wildfires in SAs occurred, in decreasing order. Those five LULCs account for over $50 \%$ of all widlfires in SAs between 2005 and 2011 (Table $5)$. 
Table 5. Corine Land Cover (CLC) class-3 land use-land covers affected by wildfires in study areas between 2005 and 2011

\begin{tabular}{|c|c|c|c|c|}
\hline $\begin{array}{l}\text { CLC } \\
\text { subclass }\end{array}$ & Land use-land cover & $\begin{array}{l}\text { Times } \\
\text { affected }\end{array}$ & $\begin{array}{l}\text { Times affected } \\
(\%)\end{array}$ & $\begin{array}{l}\text { Cummulative } \\
\text { percentage }(\%)\end{array}$ \\
\hline 323 & Sclerophyllous vegetation & 11 & 14.29 & 14.29 \\
\hline 311 & Broad-leaved forest & 9 & 11.69 & 25.97 \\
\hline 312 & Coniferous forest & 8 & 10.39 & 36.36 \\
\hline 243 & $\begin{array}{l}\text { Land principally occupied by } \\
\text { agriculture }\end{array}$ & 6 & 7.79 & 44.16 \\
\hline 324 & Transitional woodland scrub & 6 & 7.79 & 51.95 \\
\hline 332 & Bare rock & 6 & 7.79 & 59.74 \\
\hline 321 & Natural grassland & 5 & 6.49 & 66.23 \\
\hline 322 & Moors and heathland & 4 & 5.19 & 71.43 \\
\hline 222 & Fruit trees and berry plantations & 3 & 3.90 & 75.32 \\
\hline 242 & Complex cultivation patterns & 3 & 3.90 & 79.22 \\
\hline 244 & Agro-forestry areas & 3 & 3.90 & 83.12 \\
\hline 313 & Mixed forest & 3 & 3.90 & 87.01 \\
\hline 333 & Sparsely vegetated areas & 3 & 3.90 & 90.91 \\
\hline 211 & Non-irrigated arable land & 2 & 2.60 & 93.51 \\
\hline 111 & Continuous urban fabric & 1 & 1.30 & 94.81 \\
\hline 212 & Permanently irrigated land & 1 & 1.30 & 96.10 \\
\hline 221 & Vineyards & 1 & 1.30 & 97.40 \\
\hline 231 & Pastures & 1 & 1.30 & 98.70 \\
\hline 334 & Burnt areas & 1 & 1.30 & 100.00 \\
\hline
\end{tabular}

\section{Discussion}

\subsection{Environmental sustainability in SAs and their statutory zones}

Overall, the SAs assessed here showed decreasing environmental sustainability in the analysed period. However, important differences between SAs and statutory zones were found. NPs have high environmental sustainability. When compared to PPZs and SIZs, NPs experienced the least number of 'noticeable' LULC changes, and was also the statutory zone least affected by forest fires. Fire events can explain the noticeable decrease in 'coniferous forest' cover in NPs, and probably the noticeable increase in 'transitional woodland shrub' as natural landscape in process of natural recovery. Nevertheless, the noticeable decrease of 'broad-leaved forest' in NPs cannot be explained solely by wildfires, as they only affected a very small area of Cabañeros NP, according to official data (San-Miguel-Ayanz et al., 2012). Broad-leaved forests' decrease in NPs is most likely related to the planned removal of exotic tree species included under CLC subclass 311 such as Eucalyptus globulus, E. Rostrata and E. Camaldulensis that were planted in the 1950s and 1970s across important areas of the SAs of Cabañeros, Monfragüe and Doñana to produce paper pulp (Veiras \& Soto, 2011). Additionally, recurrent droughts in the analysed period, and especially in 2012 , caused greater defoliation in broad-leaved tree species than in coniferous species which are better adapted to water stress in Mediterranean environments (Spanish Government, 2015a). This might have affected the correct interpretation of the 'broad-leaved forest' subclass.

The positive environmental sustainability results of NPs related to the other statutory zones were expected, as human interventions (even managerial ones) inside NPs are legally 
highly restricted (Spanish Government, 2014). Also, management effort in the Spanish network of NPs in terms of investment and staff numbers is much higher than for other designation categories such as nature parks, though decreasing since 2005, with $248 € /$ ha and $307 \mathrm{ha}$ /worker in NPs on average versus $26 € /$ ha and 3,500 ha/worker in nature parks on average in 2010 (Múgica et al., 2012). Thus, incidents or regulation breaches leading to negative LULC changes in NPs are easily detected and rare, and funds are more available to fix them. LULC changes were smaller and less numerous in PPZs than in SIZs, as expected, given the LULC regulations affecting the former (Spanish Government, 2014), although wildfires affected both zones similarly. These results are in accordance with previous studies which also stated higher LULC stability in nationally designated PAs than in unprotected areas in Spain in previous years (Jiménez, 2009; Martínez-Fernández et al., 2015), but in contrast with a recent study on the Spanish NP network which found greater proportion of LULC change in most NPs than in their external buffer areas in the 1990-2006 period (Hewitt et al., 2016). Differences with this study may be due to the different buffer areas, techniques, NP management intensity and/or assessed periods.

The number of 'noticeable' LULC changes seems to be more related with specific socioeconomic dynamics of the SAs than to SAs' sizes or the age of NPs. Three SAs showed great LULC stability in all their zones in the analysed period: Ordesa y Monte Perdido, Aigüestortes and Caldera de Taburiente, which is encouraging as it suggests effective conservation of their natural assets inside PAs and also in their surroundings (EEA, 2006). Hewitt et al. (2016) also included those NPs (plus Timanfaya) as those experiencing the least amount of LULC changes in the 1990-2006 period, which shows long-term LULC stability and thus effective conservation in these PAs. In contrast to previous suggestions that private land ownership in Spanish PAs might reduce their sustainability (Martínez-Fernández et al., 2015) these do not seem to apply here, as the proportion of private land in those three stable NPs was very different in 2010: from less than $5 \%$ in Aigüestortes to more than $80 \%$ in Caldera de Taburiente (Spanish Government, 2012a), so sustainability factors should probably be sought somewhere else. The three are mountain ecosystems located away from the coast, main cities and major infrastructures. These biophysical characteristics are likely to have prevented negative LULC changes and 'naturally' helped to preserve these SAs' natural assets (Mas, 2005; Andam et al., 2008; Gaston et al., 2008; Spracklen et al., 2015). Moreover, Caldera de Taburiente is located in the Macaronesian region, and Aigüestortes and Ordesa y Monte Perdido are in the Alpine region, a region which showed a relatively higher stability of its LULCs compared to the Mediterranean region in the 1987-2006 period (Martínez-Fernández et al., 2015). Actually, in the 2000-2006 period, a period of accelerated LULC change in Spain, the highest proportions of LULC changes occurred in Mediterranean provinces of the country (Jiménez, 2010).

Teide's, Doñana's, Tablas de Daimiel's, Cabañeros' and Sierra Nevada's SAs showed the greatest LULC dynamism although chiefly affecting their peripheral areas. Our results agree to a large extent with those by Hewitt et al. (2016) who also found these NPs to be among the most dynamic ones in the 1990-2006 period. This indicates especially active, longterm socioeconomic contexts of difficult interpretation sustainability-wise overall (EEA, 2006), but which should make territorial planners and PA managers aware to respond quickly and soundly to local unsustainable trends. Interpreting CLC intra-class LULC changes such as those agrarian transitions dominating in Tablas de Daimiel SA are the most challenging ones, as environmental sustainability includes a different number of variables, so environmental trade-offs are expected (EEA, 2006; Gregor et al., 2016). In this protected wetland historically pressured by legal and illegal underground water extraction for agriculture (Fornés et al., 2000; Esteban and Albiac, 2012), there seems to be a progressive transformation of intensive water-consuming LULCs to less water-consumptive agrarian LULCs, or even to semi-natural LULCs through natural succession in its PPZ and NP, which indicates increasing environmental sustainability in this SA. These positive LULC changes in the NP and PPZ are likely to reflect the outcomes of a successful policy to actively purchase private land in the NP and surrounding areas by the public administration between 2007 and 2010. In that period, 1,107 hectares of primarily agrarian private land representing $50 \%$ of private land in the NP was made public together with landowners' rights on water usage, which is likely to have alleviated the overexploited status of the wetland's aquifer (Spanish Government, 2012 ). In Doñana, the most important LULC transitions are related to burnt area recovery (in its SIZ), and increase (in its SIZ and PPZ) at the expense of mature ecosystems. Numerous intra-class agrarian LULC transitions of difficult interpretation also occurred in this SA. The noteworthy increase of 'inland marshes' at the expense of 'pastures' in 
its PPZ likely resulted from the different pluviosity in 2005 and 2011, from different CLC scene dates for the same area in both years, or from a classification error, as highlighted previously (Hewitt et al., 2016).

Initial pressure was moderate to low around most NPs and PPZs by 2005 except for Doñana, where intensive water-consuming LULCs widely dominated around this biodiversity-rich coastal wetland. LULC sustainability trends have worsened overall in Doñana's SA in the 2005-2011 period and afterward, which recently made both the European Commission and the UNESCO issue formal warnings to the Spanish Government to revert existing pressures and threats (Camacho, 2017; WWF, 2017). Sustainability-wise, the most negative LULC transitions occurred in Teide's SA, affecting its three zones. Urbanisation processes greatly affected some natural and semi-natural LULCs in its SIZ and PPZ whereas wildfires affected both zones substantially and also affected the NP. Although NPs in Spain are designated in areas where no human populations exist (the only exceptions being Picos de Europa and Monfraguie, with less than 2,000 inhabitants between both; Spanish Government, 2012a), PA encroachment by residential LULCs in the vicinity of PAs has been reported globally (Trzyna, 2014), in the United States (Radeloff et al., 2010), Europe (Knapp et al., 2008), Africa (Mutuga, 2009), and Spain (RodríguezRodríguez \& Martínez-Vega, 2013), and is forecasted to worsen (McDonald et al., 2008; Güneralp \& Seto, 2013). In contrast to national trends towards great increases of artificial areas in the past 25 years (Alfonso et al., 2016), artificial LULC increase has not been a threat to the Spanish network of National Parks as a whole in that period (Hewitt et al., 2016). However, population growths of nine per cent of greater have occurred in seven of the fourteen municipalities of the official Teide's SIZ between 2005 and 2011, with a mean overall growth of $11.5 \%$, substantially higher than the remarkable $7.7 \%$ population increase of the whole Tenerife province (INE, 2017). Population trends have been most unsustainable in two of the most populated municipalities to the south of the PA: Adeje (34\% increase) and Granadilla de Abona (25\% increase). Therefore, most growth in residential LULCs in this SIZ can be explained by population growth, the rest being probably explained by holiday home construction for tourism. Artificial LULC rise also increases the probability of human-induced wildfires through greater proportion of urbanforest interface and increased human use of areas adjacent to PAs (Radeloff et al., 2010; Vilar et al., 2016). Actually, 78\% of all wildfires representing $83 \%$ of all wildfire extent in Spain in the 2001-2010 decade was humancaused, and over $50 \%$ of them were intentional (Enríquez \& del Moral, 2012). Finally, Teide's NP is the most visited NP of the Spanish network by far (Múgica et al., 2012), a fact that also increases wildfire risk. Though Teide's SIZ covers a large proportion of the area of Tenerife island outside the PA, the unsustainable local trends affecting this insular NP are worrisome and should be properly addressed by territorial planners and decision-makers. However, competencies over urban planning and PA planning and management belong to different administrations in Spain. Urban planning is a local competency whereas PA planning and management (except for locally designated PAs) are regional competencies. Moreover, competency over territorial planning and PAs often belong to different and highly changing administrative departments (of the regional administrations). Greater coordination of administrations, bodies and policies affecting environmental territorial sustainability in Spain is a long-lasting (Múgica \& Gómez-Limón, 2002) but still unmet demand resulting in unnecessary administrative complexity and inefficient outcomes (Múgica et al., 2012).

Wildfires affected most SAs and zones in the analysed period, being the most widespread recent threat to the Spanish NP network observed here. In their 1990-2006 study, Hewitt et al. (2016) found short-term wildfire evidence in Cabañeros NP, Monfragüe NP, Sierra Nevada NP and Picos de Europa NP, using exclusively CLC data. Although important resources are used to prevent forest fires affecting NPs and other PAs in Spain, between 12,000 and 25,000 wildfires affected nearly 114,000 hectares annually on average in the last decade (Enríquez $\&$ del Moral, 2012). Accordingly, 23\% of the overall management budget of the Spanish NP network between 2007 and 2010 was used to prevent forest fires by hiring fire brigades, clearing dense vegetation, creating fire-cuts or creating reservoirs (Spanish Government, 2012a). The NPs that received more funding for wildfire prevention were: Cabañeros (over $6 \mathrm{~m}$ $€)$, Doñana, and Caldera de Taburiente (Spanish Government, 2012a). The only biogeographic region in which no wildfires affected SAs in the 2005-2011 period, or NPs in the 1990-2006 period (Hewitt et al., 2016), was the Alpine region, which might be due to its less prone climatic and biomass conditions (Pausas, 2012), and/or to lower population densities in SIZs and moderate visitation levels of NPs in this region (Spanish Government, 2017 a).

Legal restrictions and managerial actions likely resulted in NPs been notably and 
systematically less affected by wildfires than the other statutory zones, except in one SA. However, PPZs were similarly affected by wildfires to SIZs. Recent changes in the Spanish forest law allow changing natural LULCs to artificial ones after forest fires (Spanish Government, 2015 ). Those legal changes cannot affect NPs, which are protected by their own law (Spanish Government, 2014), but could negatively affect their PPZs and, chiefly, SIZs by allowing environmentally unsustainable LULCs around NPs. Our results on wildfire incidence by LULCs coincide with data on the tree species most affected by wildfires in Spain between 2001 and 2010: Pinus pinaster, P. halepensis ('coniferous forest'), Eucaliptus globulus and Quercus ilex ('broad-leaved forest'), respectively (Enríquez \& del Moral, 2012). Three of the five most relevant LULCs in terms of wildfire incidence include pirophyte species for which periodic fire events form part of their natural dynamics (e.g. Pinus $s p$ ). Actually, the LULC most frequently affected by forest fires ('sclerophyllous vegetation') typically includes bushy Mediterranean species from genera such as Rosmarinus, Cistus, Lavandula or Erica (EEA, 1995) which are adapted to recurrent fire regimes that enhance their germination success and prevent progress to mature forest formations (Pausas, 2012). Burnt areas increased relevantly in three SAs on the Canary Islands, affecting all their statutory zones (except Garajonay's NP) which suggests that the increase in the number and extent of wildfires in the Canary Islands between 2001 and 2010 (Enríquez \& del Moral, 2012) might have similarly affected its NPs. Canarian SAs have the singularity of belonging to the Macaronesian region, a small biogeographic region rich in endemic biodiversity (Santamarta et al., 2014). Moreover, in the Canary Islands, over $75 \%$ of the species of conservation concern are in unfavourable or unknown conservation status (Prieto, 2016) and ecosystem services are deteriorating (Montes et al., 2011). These figures underline the importance of sustainability of LULC changes, not only in Canarian NPs and their peripheral areas, but across this entire biodiversity relevant Spanish region.

\subsection{Methodological remarks}

There are some methodological aspects of the study to comment. Firstly, peripheral zones of NPs cannot be considered completely 'unprotected', let alone PPZs, which have a degree of legal restrictions to LULC changes according to the Spanish Law on NPs (Spanish Government, 2014). It is quite usual that different PA designation categories overlap over the same areas in mature, well developed PA systems and networks such as the Spanish network of NPs (Spanish Government, 2012a; Múgica et al. 2012). Actually, all current 15 Spanish NPs are included in the Natura 2000 Network (Spanish Government, 2017 ). In this study, other such PA categories that may overlap with PPZs or SIZs completely or partially were not considered. However, existing overlaps are likely to have conferred a degree of protection to SIZs and some additional protection to PPZs or even NPs, thus probably reducing LULC changes in peripheral areas (and therefore, differences with NPs) compared to purely 'unprotected' (for SIZs) or nonoverlapping (for PPZs) peripheral areas. For instance, the PPZs of the two Andalusian NPs, Doñana NP and Sierra Nevada NP, entirely coincide with nature parks and have thus enhanced protection.

Secondly, it should be noted that the focus of our study was restricted to environmental sustainability, this being the primary aim and essential concern of any PA (Dudley, 2008), and also of the Spanish NP network (Spanish Government, 2014). Nevertheless, other important aspects of sustainability and secondary aims of PAs, such as social or economic development of local populations (Spanish Government, 2014; Alendorf \& Gurung, 2016) were not considered here. Their inclusion in future PA sustainability studies would provide a more complete picture of the global sustainability of PAs and PA networks.

Thirdly, the relatively coarse resolution of CLC data and possible classification mistakes are likely to have reduced the accuracy of the assessment (Maucha \& Buttner, 2005; EEA, 2006). Additionally, some intra-class LULC transitions are uncertain and difficult to interpret from an environmental sustainability perspective (e.g. 'sclerophyllous vegetation' from/to 'transitional woodland shrub'; Hewitt et al., 2016); moreover, some important changes in LULC management intensity (e.g., fertilizer use for many CLC agrarian subclasses) are not reflected by standard, level-3 CLC data (EEA, 2006; Gregor et al., 2016; Kuemmerle et al., 2016).

\section{Conclusions}

NPs were effective at conserving natural and semi-natural LULCs. Increased number of 'noticeable' LULC changes occurred along the statutory zones' protection gradient: from NPs through PPZs to SIZs. NPs were also the least affected by forest fires and thus, the most environmentally sustainable statutory zone. 
Wildfires outstood as the most widespread pressure across the three statutory zones of the Spanish NP network. 'Relevant' LULC changes towards artificial uses in the analysed SAs between 2005 and 2011 were numerically anecdotal, concentrating in just one SA (Teide's SIZ).

The most stable SAs regarding LULC changes were: Aigüestortes, Ordesa y Monte Perdido and Caldera de Taburiente, the two former not being affected by wildfires either and showing, thus, the greatest recent environmental sustainability of the Spanish NP network in and around PAs. In contrast, the most dynamic SAs in terms of LULC change were Teide and Doñana. Numerous complex CLC intra-class LULC transitions occurred in Doñana and Tablas de Daimiel SAs. Although the environmental sustainability interpretation of those transitions is not straightforward, positive trends are suggested in Tablas de Daimiel's NP and PPZ as a result of changes towards less water-intensive LULCs. Teide was the most environmentally unsustainable SA of the network, with numerous transitions from natural and semi-natural habitats to artificial LULCs in its SIZ, and 'relevant' transitions from natural habitats to burnt areas in its three zones. Sustainable territorial planning and management interventions in the NP network should prioritise this highly singular and pressured SA.

\section{Acknowledgements}

This paper recognises contributions through the 'sequence-determines-credit' approach. We would like to thank Gloria de Mingo, from the National Park Autonomous Body (OAPN), for providing relevant updated information on the NP network. GIS wildfire data were provided by the European Forest Fire Information System - EFFIS (http://effis.jrc.ec.europa.eu) of the European Commission Joint Research Centre. DRR was funded for this study by the Spanish Ministry of Economy, Industry and Competitiveness in the framework of the SOSTPARK project (CSO2014-54611-JIN).

\section{References}

Ahmad, C.B.; Mohd, I.H.; Abdullah, J. \& Jaafar, J. 2012. Stakeholders'perception on buffer zone potential implementation: a preliminary study of Tasek Bera, M'sia. Procedia-Social and Behavioral Sciencies, 50: 582-590.

Alfonso, C.; Avellaner, J.; Estévez, R.; García, A.; Martínez, J.; Prieto, F. \& Santamarta, J. 2016. SOS16. Sostenibilidad en España 2016. Cumplimiento de los Objetivos de Desarrollo Sostenible de Naciones Unidas. Asociación Observatorio de la Sostenibilidad. Available online

from:

http://www.observatoriosostenibilidad.com/doc umentos/SOS16_v23_PDF_final.pdf [Accessed $31 / 10 / 2016$

Allendorf, T.D. \& Gurung, B. 2016. Balancing conservation and development in Nepal's protected area buffer zones. Parks, 22.2: 69-82.

Andam, K.S.; Ferraro, P.J.; Pfaff, A.; SánchezAzofeifa, G.A. \& Robalino, J.A. 2008. Measuring the effectiveness of protected area networks in reducing deforestation. PNAS, 105(42): 16089-16094.

Butchart, S.H.M.; Walpole, M.; Collen, B.; van Strien, A.; et al. 2010. Global biodiversity: indicators of recent declines. Science, 328(5982): 1164-1168.

Camacho, J. 2017. Sociedad. Ciencia. Medio Ambiente. Ultimátum de la Unesco a España por la falta de agua en Doñana. El Periódico. Available online from: http://www.elperiodico.com/es/medioambiente/20170522/ultimatum-unesco-aespana-proteger-acuifero-donana-6053175 [Accessed 18/09/2017]

Copernicus Land Monitoring Services. 2016 a. PanEuropean. Corine Land Cover. CLC 2006. 18.5 version. Available online from: http://land.copernicus.eu/pan-european/corineland-cover/clc-2006/view [Accessed 31/10/2016]

Copernicus Land Monitoring Services. 2016 . PanEuropean. Corine Land Cover. CLC 2012. 18.5 version. Available online from: http://land.copernicus.eu/pan-european/corineland-cover/clc-2012/view [Accessed 17/10/2016]

Dudley, N. (Ed.). 2008. Guidelines for Applying Protected Area Management Categories. IUCN, Gland, Switzerland

EEA. European Environment Agency. 1995. Publications. Corine Land Cover - Part 2: Nomenclature. Available online from: http://www.eea.europa.eu/publications/COR0part2 [Accessed 26/01/2017]

EEA. European Environment Agency. 2006. Lands accounts for Europe 1990-2000. Towards integrated land and ecosystem accounting. EEA Report No 11/2006. Office for Official Publications of the European Communities. Luxembourg. Available online from: http://www.eea.europa.eu/publications/eea_rep ort_2006_11 [Accessed 26/01/2017]

EEA. European Environment Agency. 2015. Data and maps. Datasets. Biogeographical regions. Available online from: http://www.eea.europa.eu/data-andmaps/data/biogeographical-regions-europe [Accessed 29/11/2016]

Enríquez, E. \& del Moral, L. (Coord.) 2012. Los incendios forestales en España. Decenio 20012010. Ministerio de Agricultura, Alimentación y Medio Ambiente. Madrid. Available online from: http://www.mapama.gob.es/es/desarrollorural/estadisticas/incendiosforestales20012010finalmod1_tcm7-349255.pdf [Accessed $18 / 09 / 2017]$ 
Esteban, E. \& Albiac, J. 2012. The problem of sustainable groundwater management: the case of La Mancha aquifers, Spain. Hydrogeology Journal, 20: 851-863

Fornés, J.; Rodríguez, J.A.; Hernández, N. \& Llamas, M.R. 2000. Possible solutions to avoid conflicts between water resources development and wetland conservation in the "La Mancha Húmeda" Biosphere Reserve (Spain). Physics and Chemistry of the Earth (B), 25(7-8): 623627.

Gallardo, M. \& Martínez-Vega, J. 2016. Three decades of land-use changes in the region of Madrid and how they relate to territorial planning. European Planning Studies, 24(5):1016-1033.

Gaston, K.J.; Jackson, S.F.; Cantú-Salazar, L. \& Cruz-Piñón, G. 2008. The ecological performance of protected areas. Annual Review of Ecology, Evolution and Systematics, 39: 93113.

Geneletti, D. \& Van Duren, I. 2008. Protected area zoning for conservation and use: a combination of spatial multicriteria and multiobjective evaluation. Landscape and Urban Planning, 85: 97-110.

Gimmi, U.; Schmidt, S.L.; Hawbaker, T.J.; Alcántara, C.; Gafvert, U., \& Radeloff, V.C. 2011. Increasing development in the surroundings of U.S. national park service holdings jeopardizes park effectiveness. Journal of Environmental Management, 92: 229-239.

Gregor, M.; Löhnertz, M.; Philipsen, C.; Aksoy, E.; Schröder, C.; Prokop, G. \& Tramberend, P. 2016. Land resource efficiency. Draft final report D1.3. European Environment Agency.

Gray, C.L.; Hill, S.L.L.; Newbold, T.; Hudson, L.N. et al. 2016. Local biodiversity is higher inside than outside terrestrial protected areas worldwide. Nature Communications, 7: 12306. Doi:10.1038/ncomms12306

Güneralp, B. \& Seto, K.C. 2013. Futures of global urban expansion: uncertainties and implications for biodiversity conservation. Environmental Research Letters, 8 (2013) 014025, doi:10.1088/1748-9326/8/1/014025.

Hewitt, R.; Pera, F. \& Escobar, F. 2016. Cambios recientes en la ocupación del suelo de los parques nacionales españoles y su entorno. Cuadernos Geográficos, 55(2): 46-84.

INE. Instituto Nacional de Estadística. 2017. INEbase. Demografía y población. Padrón. Población por municipios. Cifras oficiales de población de los municipios españoles: Revisión del Padrón Municipal. Cifras oficiales de población resultantes de la revisión del Padrón municipal a 1 de enero. Available online from: http://www.ine.es/dynt3/inebase/index.htm?pad $\underline{\mathrm{re}=525}$ [Accessed 10/03/2017]

Jiménez, L. M. (Dir.) 2009. Sostenibilidad en España 2009. Observatorio de la Sostenibilidad en España. Alcalá de Henares.

Jiménez, L.M. (Dir.) 2010. Sostenibilidad en España 2010. Observatorio de la Sostenibilidad en España. Alcalá de Henares.
Jiménez, L.M. (Dir.) (2012) Sostenibilidad en España 2012. Capítulo especial energía sostenible para todos. 2012 Año Internacional de la Energía. Ministerio de Agricultura, Alimentación y Medio Ambiente, Madrid.

Knapp, S.; Kühn, I.; Mosbrugger, V. \& Klotz, S. 2008. Do protected areas in urban and rural landscapes differ in species diversity? Biodiversity and Conservation, 17(7): 15951612 .

Kuemmerle, T.; Levers, C.; Erb, K.; Estel, S. et al. 2016. Hotspots of land use change in Europe. Environment Research Letters, 11(6): 064020.

Mallarach, J.M. (Coord.) 2008. Protegits de fet o de dret? Primera avaluació del sistema d'espais naturals protegits de Catalunya. Institució Catalana d'Història Natural. Available online from: http://ichn.iec.cat/Avaluacio_Espais.htm [Accessed 10/03/2017]

Martínez-Fernández, J., Ruiz-Benito, P. and Zavala, M.A. 2015. Recent land cover changes in Spain across biogeographical regions and protection levels: Implications for conservation policies. Land Use Policy, 44, 62-75.

Martinuzzi, S.; Radeloff, V.C.; Joppa, L.N.; Hamilton, C.M.; Helmers, D.P.; Plantinga, A.J. \& Lewis, D.J. 2015. Scenarios of future land use change around United States' protected areas. Biological Conservation, 184: 446-455.

Mas, J.F. 2005. Assessing Protected Areas effectiveness using surrounding (buffer) areas environmentally similar to the target area. Environmental Monitoring and Assessment, 105: 69-80.

Maucha, G. \& Buittner, G. 2005. Validation of the European CORINE Land Cover 2000 database. In: Proceedings of the 25th EARSeL Symposium on Global Developments in Environmental Earth Observation from Space. 6-11 June 2005. Porto, Portugal.

McDonald, R.I.; Kareiva, P. \& Forman, R.T.T. 2008. The implications of current and future urbanization for global protected areas and biodiversity conservation. Biological Conservation, 141: 1695-1703.

Mcdonald, R.I., Forman, R.T.T., Kareiva, P., Neugarten, R., Salzer, D. and Fisher, J. 2009. Urban effects, distance, and protected areas in an urbanizing world. Landscape and Urban Planning, 93 (1): 63-75.

Médail, F. \& Quézel, P. 1999. Biodiversity hotspots in the Mediterranean Basin: setting global conservation priorities. Conservation Biology, 13(6): 1510-1513.

Montes, C.; Benayas, J. \& Santos, F. (Coords.) 2011. Ecosistemas y biodiversidad para el bienestar humano. Evaluación de los Ecosistemas del Milenio en España. Síntesis de resultados. Fundación Biodiversidad. Madrid.

Moreno, J.M. 1989. Los ecosistemas terrestres mediterráneos y el fuego. Política Científica, 18: $46-50$

Múgica, M. \& Gómez-Limón, J. (Coords.) 2002. Plan de Acción para los espacios naturales protegidos del Estado Español. Fundación Fernando González Bernáldez. Madrid. 
Múgica, M.; Martínez, C.; Gómez-Limón, J.; Puertas, J. \& Atauri, J.A. 2012. Anuario 2011 del estado de las áreas protegidas en España. EUROPARC-España. Madrid.

Mutuga, F. 2009. The effect of urbanization on protected areas. The impact of urban growth on a wildlife protected area: a case study of Nairobi National Park. IIIEE Theses 2009:15. IIIEE publications. Lund, Sweden. Available online

from: http://lup.lub.lu.se/luur/download?func=downlo adFile\&recordOId $=1513631 \&$ fileOId $=1513632$ [Accessed 18/09/2017]

Myers, N.; Mittermeier, R.A.; Mittermeier, C.G.; da Fonseca, G.A.B. \& Kent, J. 2000. Biodiversity hotspots for conservation priorities. Nature, 403: 853-858.

Newbold, T.; Hudson, L.N.; Arnell, A.P.; Contu, S. et al. 2016. Has land use pushed terrestrial biodiversity beyond the planetary boundary? A global assessment. Science, 353(6296): 288291.

Nieto, H.; Aguado, I.; García, M. \& Chuvieco, E. 2012. Lightning-caused fires in Central Spain: development of a probability model of occurrence for two Spanish regions. Agricultural and Forest Meteorology, 162-163: 35-43.

Pausas, J.G. 1999. The response of plant functional types to changes in the fire regime in Mediterranean ecosystems. A simulation approach. Journal of Vegetation Science, 10: 717-722.

Pausas, J.G. \& Vallejo, V.R. 1999. The role of fire in European Mediterranean ecosystems. In Chuvieco, E. (Ed). Remote sensing of large wildfires in the European Mediterranean basin, pp: 3-16. Springer. Berlin.

Pausas, J.G. 2012. ¿Qué sabemos de? Incendios forestales. CSIC \& Los Libros de la Catarata. Madrid.

Pérez-Cabello, F. \& De la Riva, J. 2001. Incendios forestales y degradación reciente del monte en España. El caso del prepirineo occidental oscense. In Marzolff, I.; Ries, J.B.; De la Riva, J. \& Seeger, M. (Eds.). El cambio en el uso del suelo y la degradación del territorio en España, pp: 47-72. Johan Wolfgang Goethe-Universitat Frankfurt am Main \& Universidad de Zaragoza. Zaragoza.

Prieto, F. (Coord.) 2014. Sostenibilidad en España 2014. SOS. Observatorio de la Sostenibilidad. Available online from: http://www.observatoriosostenibilidad.com/SO S\%202014\%20v22.pdf [Accessed: 12/01/2017]

Prieto, F. (Coord.) 2016. Sostenibilidad en España 2016. SOS. Observatorio de la Sostenibilidad. Available online from: http://www.observatoriosostenibilidad.com/201 6/11/23/sostenibilidad-en-espana-2016/ [Accessed: 09/12/2016]

Radeloff, V.C.; Stewart, S.I.; Hawbaker, T.J.; Gimmi, U.; Pidgeon, A.M.; Flather, C.H.; Hammer, R.B. \& Helmers, D.P. 2010. Housing growth in and near United States protected areas limits their conservation value. PNAS, 107(2): 940945.
Rodríguez-Rodríguez, D. 2008. Los espacios naturales protegidos de la Comunidad de Madrid. Principales amenazas para su conservación. Editorial Complutense. Madrid.

Rodríguez-Rodríguez, D. \& Martínez-Vega, J. 2013. Evaluación de la eficacia de las áreas protegidas. El Sistema de Evaluación Integrada de Áreas Protegidas (SEIAP). Resultados de la primera evaluación integrada de los espacios naturales protegidos de la Comunidad de Madrid. Fundación BBVA. Madrid.

Sabatini, M.C.; Verdiell, A.; Rodríguez-Iglesias, R.M. \& Vidal, M. 2007. A quantitative method for zoning of protected areas and its spatial ecological implications. Journal of Environmental Management, 83: 198-206.

San-Miguel-Ayanz, J.; Schulte, E.; Schmuck, G.; Camia, A. et al. 2012. Comprehensive monitoring of wildfires in europe: the European Forest Fire Information System (EFFIS). In John Tiefenbacher (Ed.) Approaches to Managing Disaster - Assessing Hazards, Emergencies and Disaster Impacts, pp. 87105, InTech.

Santamarta, J.C.; Naranjo, J. \& Arraiza, M.P. 2014. Challenges for future of Natural Spaces of Canary Islands, Spain. IERI Procedia, 8: 176181.

Spanish Government. 2012a. Segundo Informe de Situación de la Red de Parques Nacionales 2007-2010. I Estado de la Red. Ministerio de Agricultura, Alimentación y Medio Ambiente. Madrid. Available from: http://www.mapama.gob.es/es/red-parquesnacionales/divulgacion/Informe-Red2_tcm7281101.pdf [Accessed 25/01/2017]

Spanish Government. 2012 . Segundo Informe de Situación de la Red de Parques Nacionales 2007-2010. II. Informes por Parque Nacional: Tablas de Daimiel. Ministerio de Agricultura, Alimentación y Medio Ambiente. Madrid. Available from: http://www.mapama.gob.es/es/red-parquesnacionales/divulgacion/Informe_Tablas_tcm7281298.pdf [Accessed 25/01/2017]

Spanish Government. 2014. Ley 30/2014, de 3 de diciembre, de Parques Nacionales. Available online from: https://www.boe.es/boe/dias/2014/12/04/pdfs/B OE-A-2014-12588.pdf [Accessed 24/01/2017]

Spanish Government. 2015 . Resumen de las principales iniciativas desarrolladas dentro del Plan de Seguimiento y Evaluación de la Red de Parques Nacionales. Available online from: http://www.mapama.gob.es/es/red-parquesnacionales/boletin/resumen-seguimientoevaluacion-red tcm7-408114.pdf [Accessed: 01/03/2017]

Spanish Government. 2015 b. Ley 21/2015, de 20 de julio, por la que se modifica la Ley 43/2003, de 21 de noviembre, de Montes. Available online from:

https://www.boe.es/diario_boe/txt.php?id=BOE -A-2015-8146 [Accessed 18/09/2017]

Spanish Government. 2016 . Regiones biogeográficas $y$ regiones marinas. Available online from: http://www.mapama.gob.es/es/biodiversidad/te 
mas/espacios-protegidos/red-natura2000/rn_pres_const_reg_biogeo_y_marinas.asp x [Accessed: 16/01/2017]

Spanish Government. 2016 . Real Decreto 389/2016, de 22 de octubre, por el que se aprueba el Plan Director de la Red de Parques Nacionales. Available online from: https://www.boe.es/boe/dias/2016/10/24/pdfs/B OE-A-2016-9690.pdf [Accessed 10/03/2017]

Spanish Government. 2016. Red de Parques Nacionales. SIG: Cartografía. Descarga de cartografía de la Red de Parques Nacionales. Available online from: http://www.mapama.gob.es/es/red-parquesnacionales/sig/ [Accessed 10/03/2017]

Spanish Government. 2017 a. Ministerio de Agricultura y Pesca, Alimentación y Medio Ambiente. Red de Parques Nacionales. La Red: Gestión. Red de Parques Nacionales: Visitantes. Available online from: http://www.mapama.gob.es/es/red-parquesnacionales/la-red/gestion/visitantes.aspx [Accessed 09/03/2017]

Spanish Government. 2017 . Ministerio de Agricultura y Pesca, Alimentación y Medio Ambiente. Red de Parques Nacionales. La Red. Reconocimiento internacional de los Parques Nacionales. Available online from: http://www.mapama.gob.es/es/red-parquesnacionales/la-red/internacional.aspx [Accessed 19/09/2017]

Spracklen, B.D.; Kalamandeen, M.; Galbraith, D.; Gloor, E. \& Spracklen, D.V. 2015. A global analysis of deforestation in moist tropical forest protected areas. PLOS ONE 10(12): e0143886. doi:10.1371/journal.pone.0143886

Terra, T.; Ferreira, R. \& Cortijo, D. 2014. Land use changes in protected areas and their future: The legal effectiveness of landscape protection. Land Use Policy, 38: 378-387.
Trzyna, T. 2014. Urban Protected Areas: Profiles and best practice guidelines. Best Practice Protected Area Guidelines Series No. 22. IUCN, Gland, Switzerland. Available online from:

https://cmsdata.iucn.org/downloads/urban_pa_b pg 22 front matter 14 may 2014 final 3.pdf [Accessed 02/03/2017]

UNESCO. 2016. Natural Sciences. Environment. Ecological Sciences. Biosphere Reserves. Available online from: http://www.unesco.org/new/en/naturalsciences/environment/ecologicalsciences/biosphere-reserves/ 25/01/2017]

Veiras, X. \& Soto, M.A. 2011. La conflictividad de las plantaciones de eucalipto en España $y$ Portugal. Greenpeace. Available online from: http://www.greenpeace.org/espana/Global/espa na/report/bosques/InformeEucalipto2011.pdf [Accessed: 01/03/2017]

Vilar, L.; Gómez, I.; Martínez-Vega, J.; Echavarría, P.; Riaño, D. \& Martín, M.P. 2016. Multitemporal Modelling of Socio-Economic Wildfire Drivers in Central Spain between the 1980s and the 2000s: Comparing Generalized Linear Models to Machine Learning Algorithms. PLoS ONE, 11(8): e0161344. doi:10.1371/journal.pone.0161344

WWF. World Wildlife Fund. 2017. Preventing Paper Parks: How to make the EU laws work. WWFEU Report 2017. Available online from: http://wwf.panda.org/about_our_earth/all_publica tions/?291910/Preventing-PaperParks\&dm_i=2GI3,10RBI,4TLQLQ,2ZEEG, 1 [Accessed: 20/09/2017]

Xun, B., Yu, D., Liu, Y., Hao, R., and Sun, Y. 2014. Quantifying isolation effect of urban growth on key ecological areas. Ecological Engineering, 69: 46-54. 